In chronie eases there is exacerbation of the eharacteristie symptoms on exertion, cough and frequently on deep inspiration.

Trentment. In the aeute cases the treatment is that of any pleuritis. We have found that eold applieations, in the form of ieed-linen strips, applied (and frequently ehanged) to the affeeted side for two hours, is most effieacious. Of eourse, sedatives are used when neeessary. Strapping the lower ehest and upper abdomen seens to give the greatest relief, and many of our elironie eases return to us asking that their sides be strapped. 'They lave found that after the side has been strapped their pains will be relieved almost immediately and that they will be free from their annoying symptoms for from several weeks to montlis.

We are indebted to Mr. R. Isaacs for the aeeompanying eharts.

\title{
BIBLIOGRAPHY.
}

1. Griffitl: Jour. Am. Afed. Assn., 1903, xi, 531.

2. Iferrick: Jour. Am. Med. Assn., 1903, xi, 535.

3. Capps: Arch. Int. Med., 1911, No. 6, viii, 717.

4. Capps: As. Jour. MEv, Sc., 1916, No. 3, cli, 333 .

\section{THE FRACTIONAL EXAMINATION OF THE DUODENAL CONTENTS.}

\author{
Br Max Eishon, M.D., \\ phOELSSOH OF MPDICINE AT THE NEW YOHK POSTGHADUATE MEDICAL RCHOOL, \\ NEW ronk.
}

'T'ne duodenal contents are of intrinsie value for the welfare of the organism. The main process of digestion is accomplished by the proper working and eorrelation of the different fluids entering into this comparatively small part of the digestive apparatus (the duodemum). It is quite natural that a study of these secretions from every possible viewpoint will prove nseful plypsiologically as well as pathologieally.

In sereral previous eommunieations I published my results eoncerning the examination of the duodenal contents. Isually these explorations of the dnodenal seeretions had been done either in the fasting eondition of the patient or some time after the ingestion of either tea and sugar or bouillon. No partieular attention had been paid as to the length of time after the meal the examination lad been performed.

It appeared to me worth while to undertake a eomparative

1 Read before the Association of Ameriean Physicinns, at Atlantic City, N. J. Nay, 1018. 
stndy between the resnlts of the examination in the fasting condition and at different periods after certain test meals. Inasmueh as the duodenal tube must have a comparatively narrow lumen, solid food, even meehanieally well comminuterl, would be apt to clog up the instrument, and would therefore be inappropriate for these examinations.

For these reasons I had already formerly employed either tea and sugar or boullon as preparatory meals.

In the present investigation I selected a cup of beef bouillon (one bouillon cube, usually Armour \& Co., to one eup of hot water) as the proper test meal. Beef being a strong stimulant for the digestive secretions seemerl to answer well our purpose.

Examination of the duodenal contents was first made in the fasting condition, then a elp of beef bouillon was given by mouth and the duodenal contents aspirated every half-hoir for a period of two hours (fractional examination).

In order to lave a larger eollection of eases, we utilized many patients who were on dhodenal alimentation of duodenal fluid instillation for this purpose. In these eases the explorations ean be earried out witl the greatest ease, for they have the tube already in the riglit place. But we also took patients not aeeustomed to the tuhe, prineipally in eonditions in which the lile or panereatic secretions liad to be examined any way. We also lad two persons without any subjective syinptons, representing the normal, who were willing to undergo this examination for the benefit of seience (George C. and Miss Ruth M., to whom I express my thanks for eoöperation).

In all these additional cases the mode of procedure was as follows: The patient was given the dnodenal tube in the evening after a light supper. Attention was paid to the length of tube which had entered the buccal cavity before retiring. IIark III of the tube should liave reaclied the montli; if not, the patient is given milk or water and the tube in this way made to go in beyond the III mark before going to sleep. In patients who sleep restlessly it is advisable to attacl the tube, lying outside the month, with a pieec of adhesive plaster to the elieek, in order to avoid a pulling out of the instrument during the night by any inadrertent motion. In the early morning the eapsite end of the tube has usually reached the duodenum and the desired examination ean be performed.

'T'he specinens obtained were examined within one or two hours after aspiration. 'The quantity and appearanee of the fluid, in regard to color and elearness, then the reaction, whether nentral, alkaline or acisl, and the figure of alkalinity or acidity, were aseertained. For the renetion, blue and red litmus paper was used, while the degree of alkalinity was determined by titration, with metbyl-orange and $\frac{1}{10}$ standard solution of hydrochlorie acid. The ferments (amylopsin, steapsin and trypsin) were estimated by 
employing agar tulbes ${ }^{2}$ and ganging the amounts by the digested piece of the agar eolumn, stated in millimeters. 1 an greatly obliged to Dr. O. Ilensel for laving examined seven speeimens from my cases.

Altogether, I have examined the duodenal eontents of thirtytwo people witlı the fractional method. In all the bouillon test ineal was used; in uiost of the patients the dnodenal eontents were also examined in the fasting condition. It will be best to first give the results of these examinations in table form.

Rexlates. The table on pages $820-826$ begins with two apparently normal individuals (Gromp I). In Case 1, IR. M., the alkalinity of the duodenal contents in the fasting condition is 30 while one-lualf hour after the bonillon test meal it is only 10, then it goes to 25 , 25 and ultimately to 30 . The ferments, likewise, are strongest in the fasting eondition while they are weakest one-lialf hour after tle test meal, to inerease in strength later on.

Case 2, also belongiug to the apparently normal, shows already a dificrent relation. Here the allialinity in the fasting eondition is 20; lalf an hour after the test meal it is the same. The ferments in the fasting eondition are weaker than half an lour after the houlillon; one liour after the test meal they are strongest while later the stenpsin ferment grows weaker.

Group II. Five cases witl normal gastric secretion, $\mathrm{ICl}+$, acidity (60. In A. M., R. S. and J. M. W. the alkalinity increases up to the end of the first loour, it then slightly diminishes. In Mrs. 'I. T. and IV. B. the alkalinity' shows a stemly inerease up to the end of the two hours.

'The ferments slow great variations, but, on the whole, their strengtl, on an average, is greatest about onc hour after the boullon test meal.

Group 11l. kleven cases of liyperchlorlyydria, in three of which the fasting duodemal contents were examined, sliow in two a slightly diminished alkalinity one-half hour after the bonillon test meal, while in one there was apparently no difierence.

'The figures of the alkilinity fhotuated between 5 and 40 and were usually highest between one hour and one and a half hours after the boullon test meal. 'The ferments, likewise, showed, in a general way, the sanc peculiarity, lyeing strongest about that time.

Group IV eomprises 4 eases of subacidity and 1 of elolelithiasis, with unknown gastric secretion. The degree of alkalinity fluetunted between 10 and 35 ; once it was 70 ant once in the same patient, with the bilitury fistula, it was found to be aeid or -10 . 'The strength of the ferments was usually highest between one and a half hours after the houillon test meal.

2 Einhorn, Max: Asar Tubes for the Estimation of the Pancreatic Ferments, Med. Record, Janunty 15, 1910; also Recent Siudies of Pancreatic Secretions, MIed. Record, January $12,1915$. 


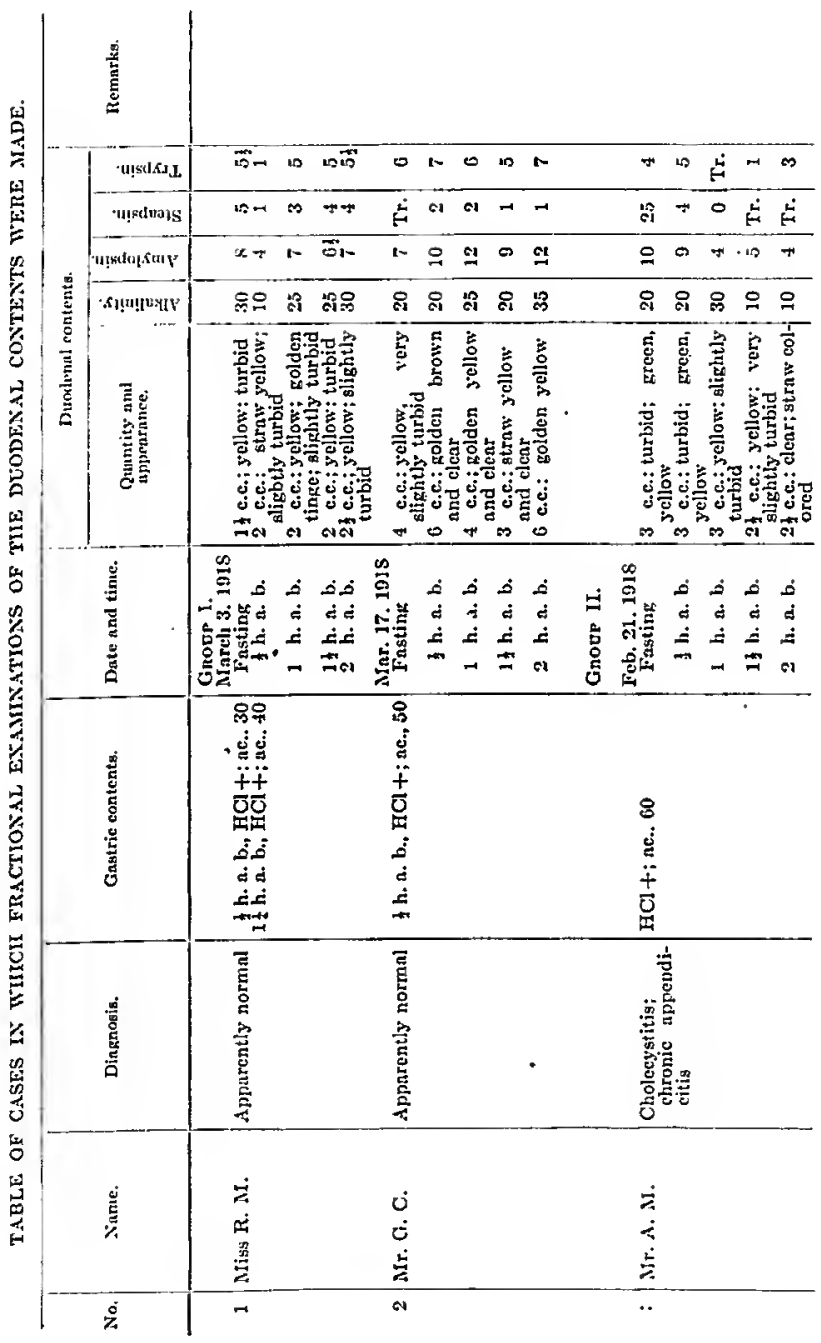




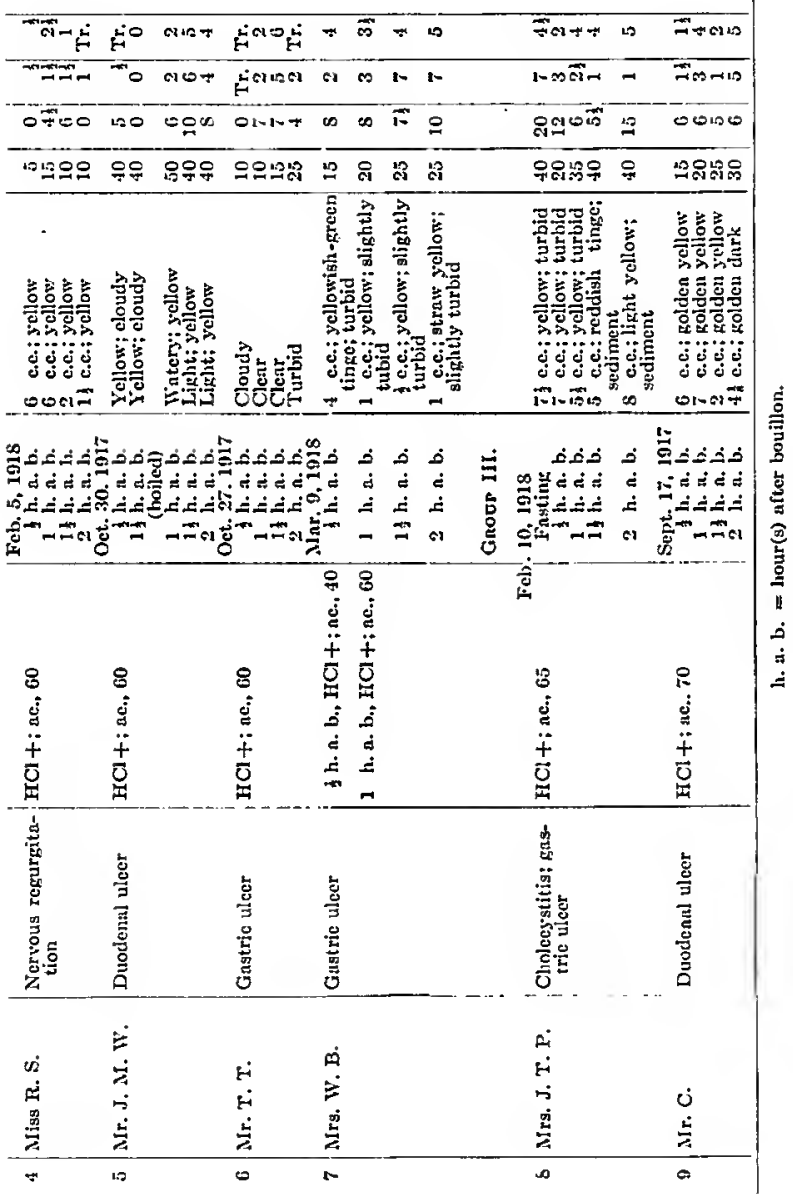




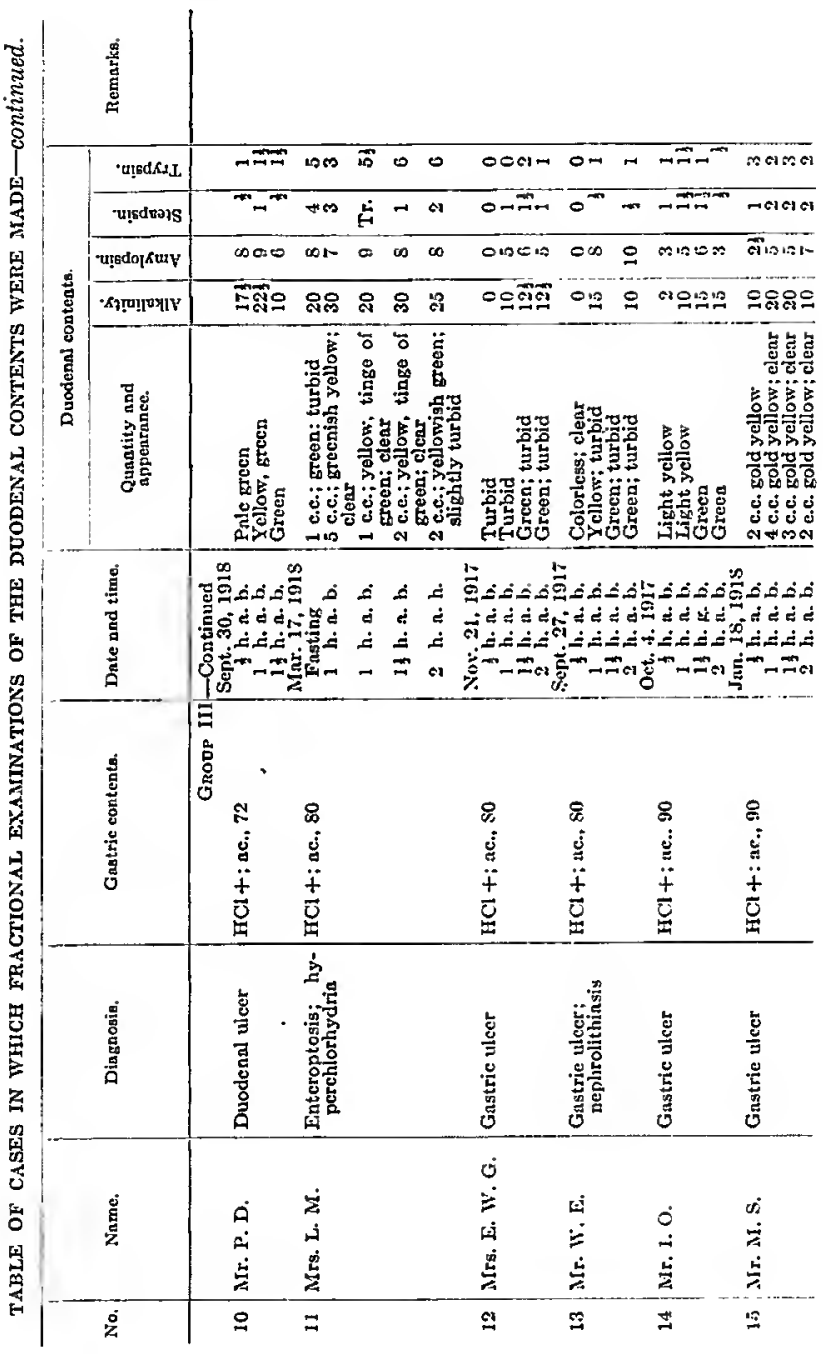


EINIORN: EXAMINATION OF THE DUODENAL CONTENTS 823

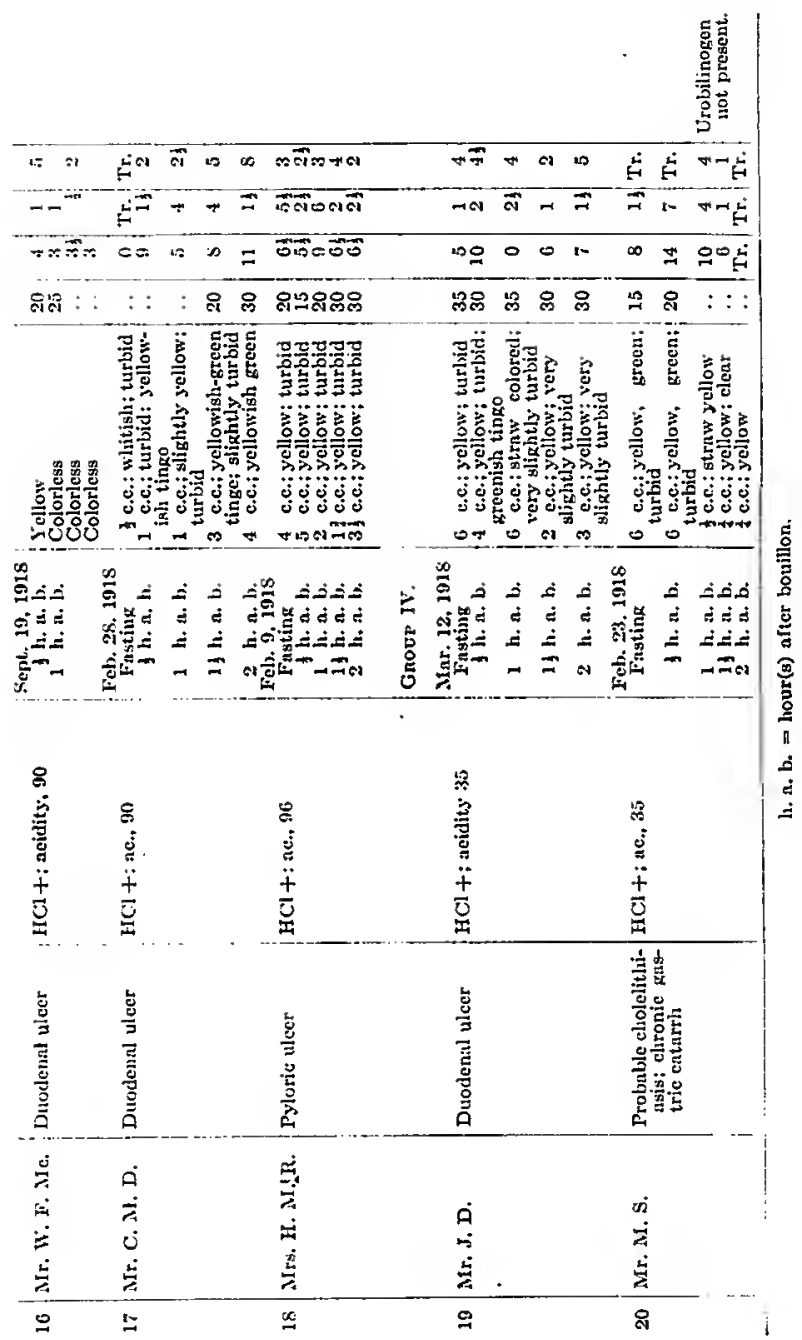


S24 EINIORN: EXAIINATION OF TIE DUODENAL CONTENTS

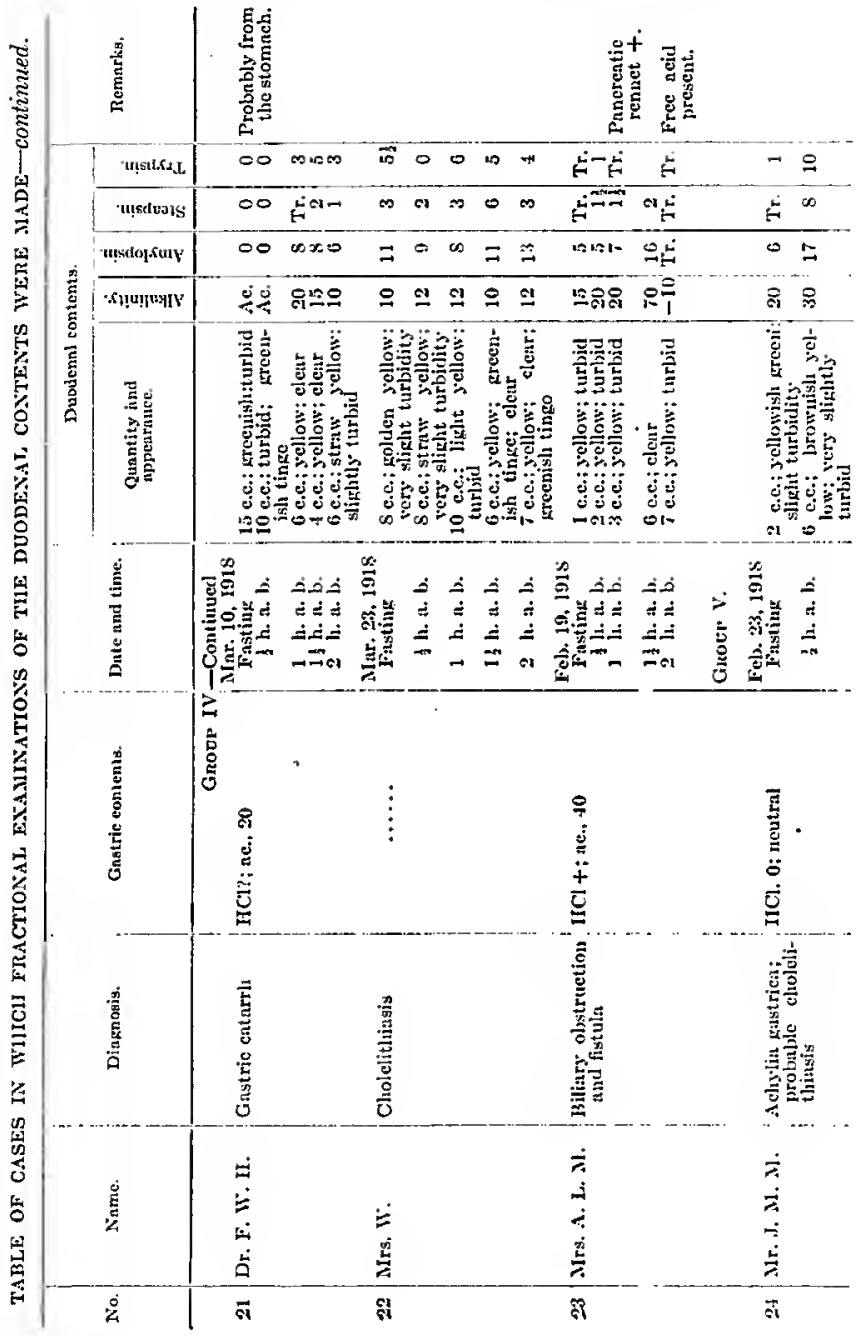



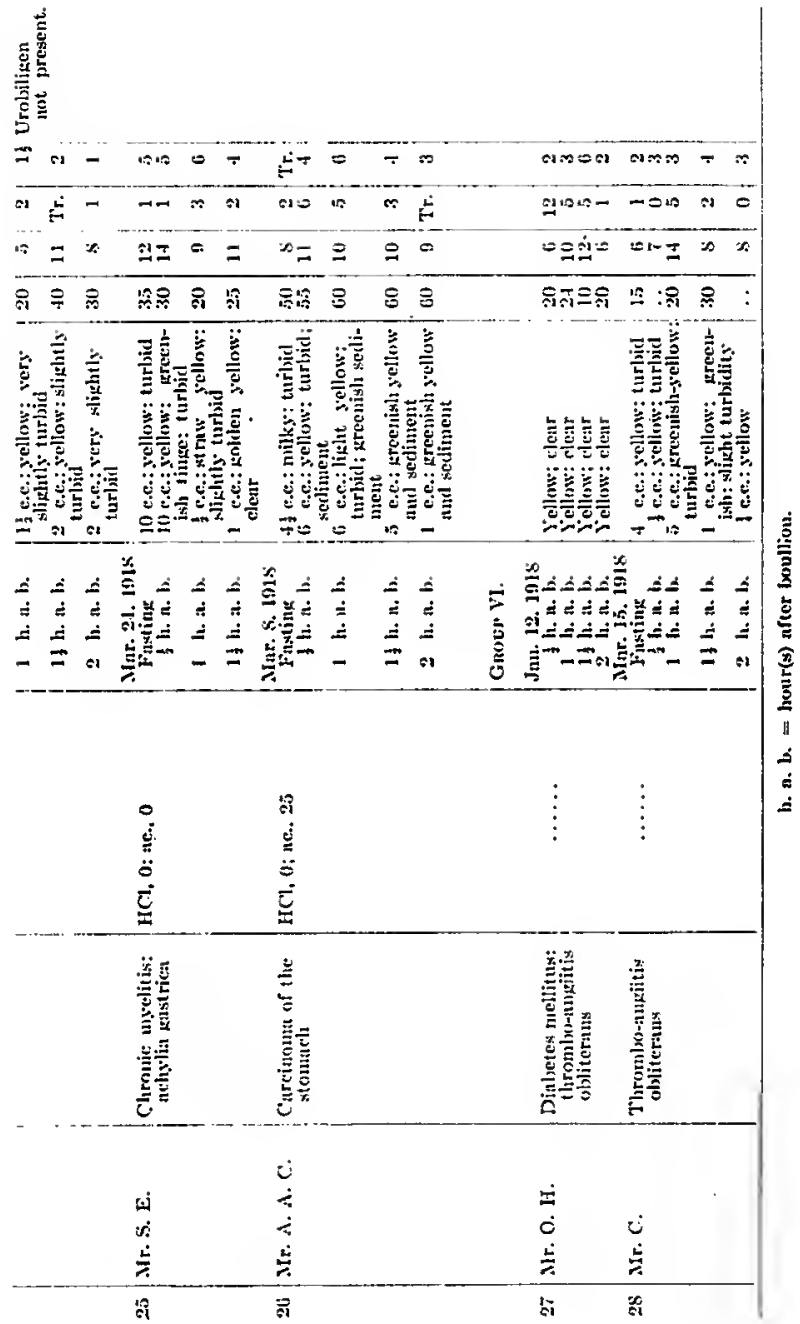


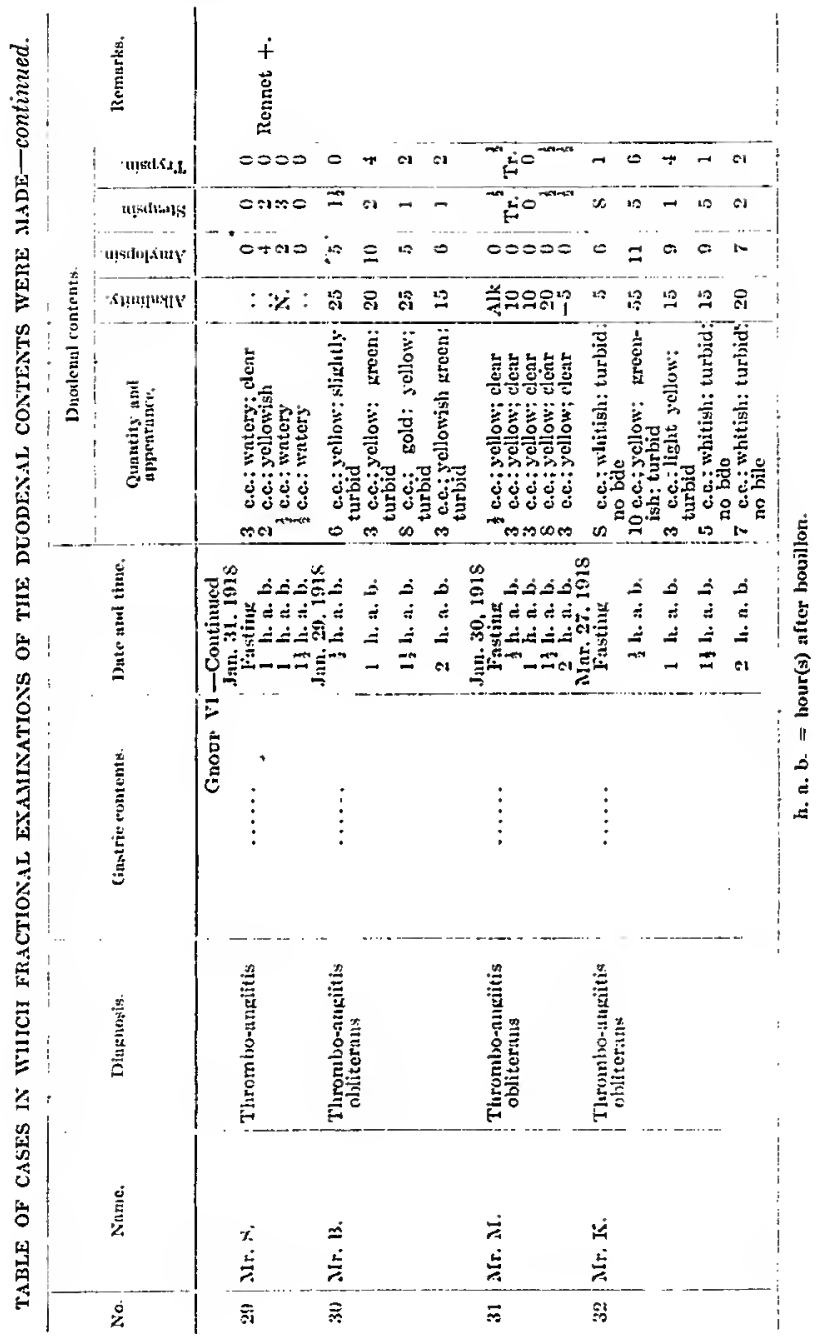


Group V eomprises 3 cases of achylia, 2 benign and 1 complieated with eaneer of the stomaeh. The alkalinity fhetuntes between 20 and 40 in the 2 benign eases and between 50 and 60 in the cancer ease. The strength of the ferments is lighest between lialf an hour and one lour after the bouillon test meal.

Group VI. Six eases of thrombo-angiitis obliterans, one of whieh was complieated with dinbetes mellitus, were likewise examined. They were all patients of Dr. Willy Meyer and were trenterl by duodenal instillation of Ringer's solution. I an greatly indebted to I)r. Willy Meyer for permission to examine their panerentie function. 'The alkalinity was, on an average, somewhat lower than normal, fluctuating between 10 and 24; once it was 5 and onee 55 .

In 3 of the 6 eases the ferment aetivity was at times greatly reduced (Cohen, Scherr, Metloff), the steapsin ferment showing the greatest variations.

Ericnisis. The grouping of the table wns arranged necording to gastric secretion in order to see whether the latter lias any bearing on the alkalinity curve. $A$ priori, onc wonld expect a lowered alkalinity in cases of hyperchlorhydria and conversely an increased alkalinity in eases of subacidity. This seems to be true in a certrin measure, but not constantly so. It scems therc are other factors besides gastric secretion which play a part in regulating the degree of alkalinity of the duodenal coutents. Chicf among these are the pancreatic and duodenal juices and the bile. Each one of these is liable to have its own peenliarities and show alterations in discase.

It appeared worth while to look at the different types of alkalinity curves found, rcgardless of gastric juice or any disease present.

The accompanying types of alkalinity curves ean be casily discerned.

Type 1 (Chart I). Decrease of alkalinity during the first laalf hour after tbe bouillon, then a steady inerçase.

Type 2 (Chart III). Increase of alkalinity between one-half and one hour af ter the bouillon, then slight decrease. Cliart II belongs to Type 1, Chart IV belongs to Type 2.

Type 3 (Chart V). Inerease of alkalinity during first half-hour after the bouillon, then slight decrease up to one hour, then again inerease to one and a half hours, therempon again a deerease.

Type 4 (Chart VI). There is first a stendy inerense of alkalinity up to one and a half hours after the bouilon test meal then an abrupt deseent of the eurve, so that at two hours after the bouillon the eontents are aeid instead of alkaline.

of the three ferments each shows its individual peeuliarities; the strength of one ferment eannot be ganged by that of the other. It is possible to asecrtain tbe strength of each ferment at the different periods after tbe test meal and express it in the form of a eurve. But cach one (A.S. T.) has its own eurve. 

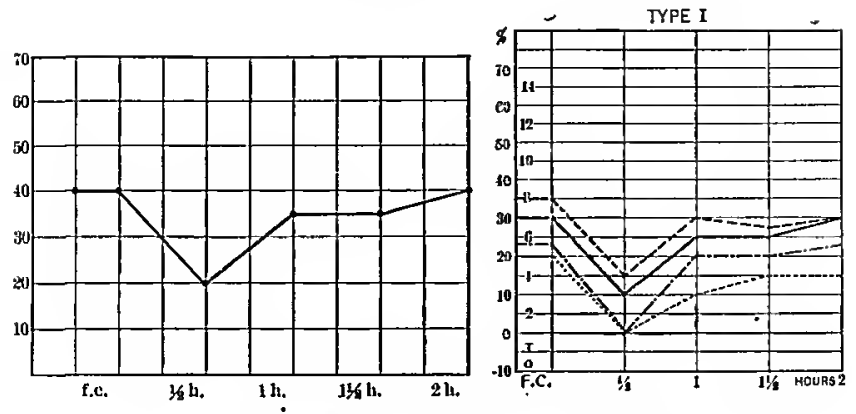

Chsnt I.-Cnse of Aliss R. M. (No. 1), Alkalinity curve, Type I.

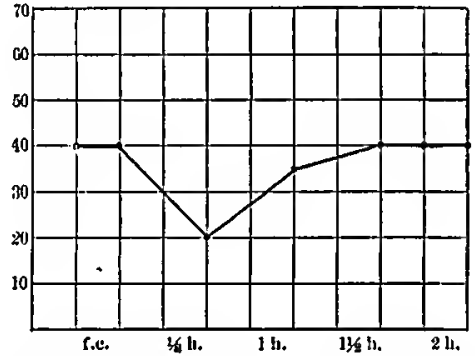

Chant II.-Casc of Mrg. J. T. P. (No. 8). Alknlidity curvo, Typo I.
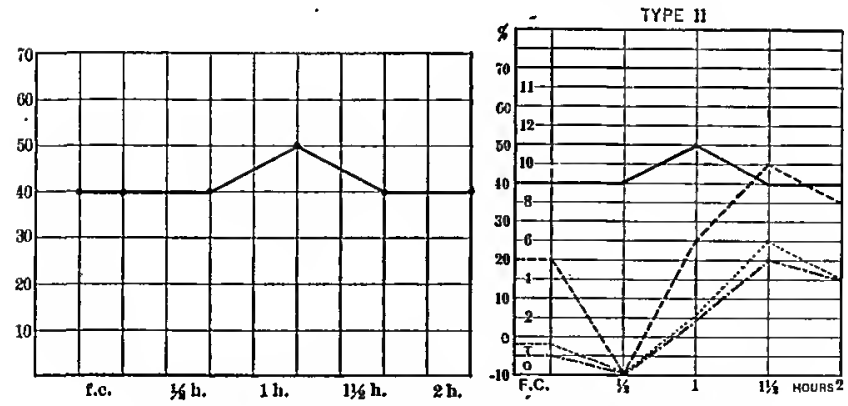

Chant III,-Case of Mr. J. M. W. (No. 5), Alkalinity curve, Typo II. 
EINIORN: EXAMINATION OF TIE DUODENAL CONTENTS

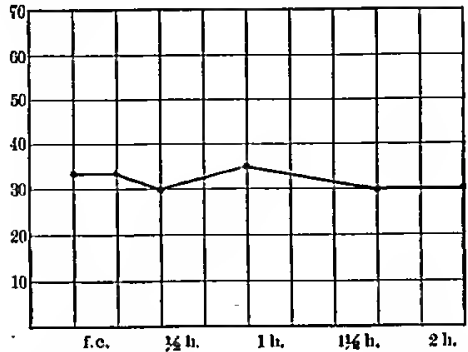

Chant IV.-Cose of Mrs. J. D. (No. 19). Alkalinity curve, Type II.
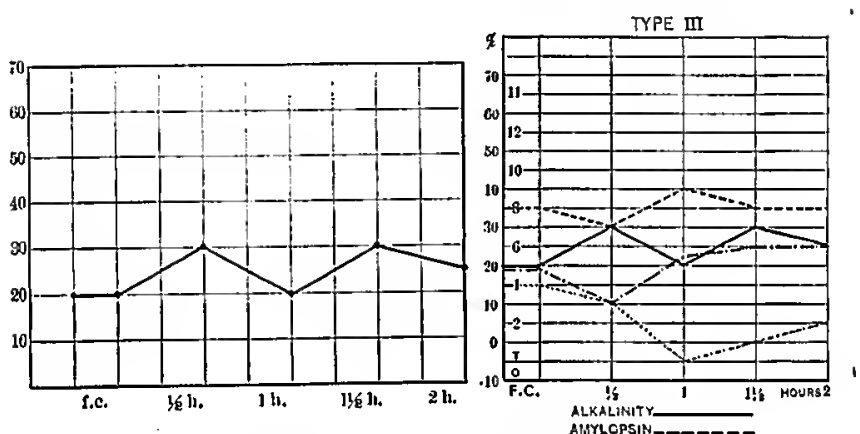

Cirat V.-Case of MIts. L. M. (No. 11). Mlalinity curve, Type III.
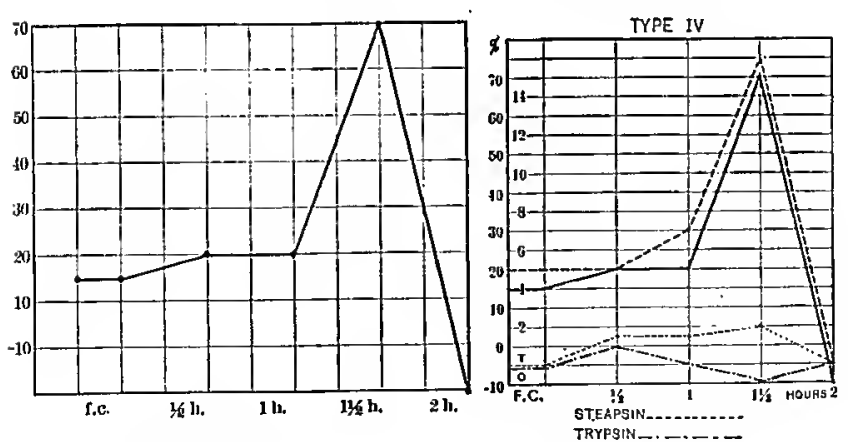

Chant Vl.-Case of Mrs. A. L. M. (No. 23). Alkaninity curve, Type IV. 
Objecr of Determinisci tue Alkalinjty. The pancreatic secretions act best in an alkaline medium. The reversion of the aeid gastric contents into an alkaline mixture is an important function of the dnodcnum and its neighboring organs.

It ean be ersily imagined that in pathological conditions this harnomions work in having the right medium will be lacking. We may then have eonditions in which the degree of alkalinity is too high, or again too low, i. e., diminished alknlinity or slight acidity.

At What True is it Best to Examine tile Duodenal ConTENTs? The fasting dnodenal contents nisully consist of some panereatic seeretion and bile, perhaps also dnodenal seeretion. 'The pancreatie juiee this time is generally wak in ferment activity and gastric contents arc not adinixed thercin.

The dnodemal eontents one to one and a half hours after the boullon test meal represent a clyyle embracing the panereatie jnicc at the height of activity, bile, dnorlenal seeretion and an admixture of gastric elyyme.

'To facilitate the diagnosis of liver and gall-bladeler lesions it appears that the examiuations in the fasting state will give the best results. For liere the investigation of the bile, in as pure a statc as we can obtain it, will form the main object.

In pancreatic affections, also in all conditions in which the prineipal part of the digestive act should be investignted, it will be best to examine the duodenal contents one to one and a half hours after the test meal. The height of the pamereatic activity found at this moment and also the reversion of the admised gastric elyyme from an acid to an alkaline medium, which is a very important funetion of the drodenum, make this time best sulted for the above purposes.

\title{
CERTAIN ASPECTS OF THE CLINICAL VALUE OF THE ESTI- MATION OF KIDNEY FUNCTION.'
}

\author{
By Edwand H. Mason, M.D., \\ HONTIEAL, CANADA. \\ (liron the Medieal Clinic of the Royal Viclorin Hospital, Montreal.)
}

Duning this past year information upon several points in kidney funetion bas aceumulated in this clinic, which we believe to be of suffieient interest to warrant its publiention. 'The material npon each of the questions presented is somewhat limited, but we hope that it will be of value to those engaged in sinnilar work.

The neecssity of determining kilney function by a combined

1 This work was tnade possible by a grant from tho James Cooper Fund of McGill Univergity. 